\title{
Institutional Factors Affecting Implementation of Strategic Plans in TVET Institutions in Nairobi County, Kenya
}

\author{
Monica Njeri Gachunga* \\ Institutional Factors Affecting Implementation of Strategic Plans in Tertiary Institutions in Nairobi County, \\ Kenya.
}

*Corresponding Author: Gachunga, M. N, Institutional Factors Affecting Implementation of Strategic Plans in Tertiary Institutions in Nairobi County, Kenya.

\begin{abstract}
The motive of this paper is to assess the factors that affect the implementation of strategic plan among tertiary institutions in Nairobi County, Kenya. Strategic plans are known to be key performance drivers in most organizations across the globe. Through strategic planning, a pathway is set through which institutions formulate a framework to achieve their goals and use the available resources for enhanced performance. Technical and Vocational Training colleges in Kenya have been on the far-front of enhancing industrialization through equipping learners with skills that are necessary for ultimate production. These institutions have however failed to obtain their full capacity where the major argument has been they are unable to come up with proper strategies to steer their performance. This study therefore, seeks to establish the factors that affect the implementation of strategic plans by the TVET institutions in Nairobi County. Specifically, this paper sought to assess the effect of resource availability, institutional structure, management competency and organizational policies on the implementation of strategic plans among the TVET colleges. A descriptive research design was adopted while the target population was the TVET institutions in Nairobi County, Kenya. The management team these institutions were surveyed comprising of three levels of management (top, middle and bottom level). A structured questionnaire was used to collect the data which was analysed using both descriptive and inferential statistics. The findings revealed that availability of resources, proper management and leadership, a flexible organizational structure and properly aligned policies significantly affected the implementation of the strategic plans among the TVET colleges. The study therefore recommended that the government ought to allocate adequate funding while the management of the institutions embrace proper leadership and foster training so as to steer implementation of the strategic plans which are key to institutional performance.
\end{abstract}

Keywords: Strategic plan, Implementation, TVET Colleges.

\section{INTRODUCTION}

\subsection{Background of the Study}

In the wake of the modern World where dynamisms and unpredictable operation environments are the norm, strategic planning remains to be a key tool to forecast and plan-ahead as a way of coming up with measures and strategies to achieve the set goals. Most organizations including public and private have tuned to strategic planning so as to spearhead proper use of their resources as well as achieve the best of their capacity (Walsh, Weber \& Margolis, 2013). According to Lehtimäki and Karintaus (2012), strategic planning is the process of documenting and developing a framework on the direction in which the company seeks to take in a given period of time and focusing the available inputs towards the achievement of the set goals. Through strategic planning, organizations have a foreseeable future expectations which defines the pace hey ought to adopt in order to attain the expectations of the shareholders.

Strategic planning is a process that focuses on strategic and operational goals, objectives and strategies based on organizational policies, programs and activities that are designed to achieve the institution's aims and desirable results (Tapera, 2016). According to Poku (2012), strategic planning ought to be action-oriented planning where it is utilized when it is coupled with implementation and this is often the point where the process fails. According to the World Bank (2011), while strategic planning is the process by which leaders of an organization determine what it intends to be in future and how it will reach this targeted level or position, the conceptualization of these plans and executing them practically remains just but a dream in majority of the firm. This takes us to the implementation of the strategic plans. 
Most organizations including the TVET institutions in Kenya are, yes, adopting strategic plans and coming up with very instrumental and properly-framed documents to show what they need to do to achieve their set goals. Implementing these plans has been found to the main step in the entire process where most of the institutions get stuck (Elnaga\& Imran, 2013). Ireri and Deya (2019) define strategic plan implementation as the process of ensuring execution of the steps, strategies and plans set in the strategic plan by ensuring adequate resource supply, providing proper leadership and offering the appropriate skills to perform the defined roles and duties.

Rotich (2013) explains that a strategic plan can be termed to be successfully implemented when the articulations in the provided strategic plan have been clearly and effectively executed and the final results obtained. This however is possible when the organization's administrative elements have a strategy supportive structure, a supportive budget, competent employees in right jobs, well laid down performance targets, internal supportive administrative systems, and visionary leadership that motivates and manages the change process in a conducive, innovative and responsive work environment.

Most of the well-doing higher learning institutions across the World have been known to uphold strategic planning and proper implementation of the set strategies and plans. In a similar motive, the Kenyan Government came up with a policy that all the learning institutions in the country especially the public institutions ought to come up with strategic plans to outline their future growth-channel and how to enhance effectiveness in learning (GOK, 2013).

The strategic plans are to answer the questions; where are we from? Where are we now? Where are we intending to go? How do we get there? With these questions answered, the institutions can now continue thriving knowing what to do and utilizing the resources in the right ways. The education structure in Kenya has evolved overtime, with major changes having been instituted in the 1980s. Mackay report in 1984 introduced the 8-4-4 system of education. All technical high schools in the country were converted to technical training institutes (TTIs) to admit and equip high school graduates with vocational skills (Sessional Paper No.1 of 2005).The TTIs fall under Technical Vocational Entrepreneurship Training (TVET) curriculum and their objectives are to provide and promote life-long education and training for self -reliance (Sessional Paper No.1 of 2005). In 2003, a Rapid Appraisal on the status of TVET curriculum was initiated to undertake the development of a National Skills Training Strategy and to implement the necessary reforms along with a legislative framework for a comprehensive TVET system. As a result of the appraisal, investment in education and training was identified as one of the pillars of the Government's overall economic recovery strategy. The report advocated for the development and implementation of strategic plan.

\subsection{Statement of the Problem}

Technical training institutions play a critical role in building a country's economy through providing the appropriate technical skills required in job market (GOK, 2016). While most of the Universities and other higher learning institutions majorly focus on managerial and administration skills, TVET colleges provide the actual technical skills that promote innovation and self-employment (Wanyonyi\&Muturi, 2015). Despite their role in the economy, the institutions have experienced minimal growth with declined intake levels and low rated of completions with inadequate infrastructure and skills to offer the required training (Gakungu et al., 2012). While strategic planning was found to be a key missing factor, most of these institutions have come up with the appropriate strategic plans but little or no change has been observed.

It still remains clear that the TVET colleges have a long way to go as far as meeting their mandate is concerned. Empirical studies have proposed that the TVET colleges and other learning institutions ought to embrace strategic planning as a way of promoting their performance and growth (Ndegwa, 2014). While at this, following the government's directive for the educational institutions to have strategic plans, it implies that most of these institutions have embraced strategic planning and little change can be observed. The question therefore remains; are the strategic plans implemented in the TVET colleges? This study seeks to answer this by assessing the factors influencing the implementation of strategic plans in the TVET colleges in Nairobi County, Kenya. 


\subsection{Objectives}

- To assess the effect of organization structure on the implementation of strategic Plans in TVET colleges in Nairobi County, Kenya

- To examine the effect of institutional Policies on the implementation of strategic Plans in TVET colleges in Nairobi County, Kenya

- To establish the effect of availability of resources on the implementation of strategic Plans in TVET colleges in Nairobi County, Kenya

- To determine the effect of management competency on the implementation of strategic Plans in TVET colleges in Nairobi County, Kenya

\section{LITERATURE REVIEW}

\subsection{Theoretical Review}

\subsubsection{Resource Dependence Theory}

Resource is a supply of assets such as money, materials and staff that enables organizations to function and prosper (Cullati, Stéphane, Kliegel, Widmer\& Eric, 2018). Among all these resources, money is the most important because it activates other resources. Money also is a monetary resource in a business oriented economies because it is a determinant of expansion or contraction of other resources (Samuelson \& Nordhaus. 2004). According to Preffer and Salancil (1978), RDT is the study of the relationship between organization and its external resources. The theory further explains that organizations depend on multidimensional resources such us labor, capital, raw materials and land to operate.

\subsubsection{Competency Theory}

The competency theory was first developed by David MacClland in 1980s. Since then the theory has undergone further modifications with an aim to make it more encomium to the literature. The competency model seeks to outlay the need for organizations to focus on the abilities of the workers to handle organizational issues and be more productive to the organization. According to the competency model, the abilities and skills expressed and possessed by the team leaders as well as the team members determine the extent to which the processes in a given activity is integrated for achievement of a common goal (Wills, 2011).

\subsubsection{Contingency Theory of Leadership}

Contingency theory of leadership attempts to contemplate that the methods of leadership and tactics used to provide leadership by a certain leader depends on the contextual situation in which the leader effectively develops his own style of leadership to right situation. The main goal of this theory is match the leader's style with the compatible situation (Gupta, 2009). Contingency theory of leadership is used to create profiles of the leadership for organizations by comparing the styles with the situations that are proven to be most successful. As stated by Gupta, the theory is helps the companies to know the best types of people who would fit in each position of the organization during the openings.

\subsubsection{Systems Theory}

The systems theory was first introduced by von Bertalanffy in early 1920s with an attempt to bring out into context on the organizational formation and how it could help in enhancing organizational performance (Monks and Minow, 2007). The theory explains organizational behavior as the intersection of the effects of the multiple interrelated systems. The organization is seen as a system built by energetic input and output where the energy coming from the output reactivates the system. Social organizations are then open systems due to their material exchanges with the environment. 


\subsection{Conceptual Framework}

Independent Variables

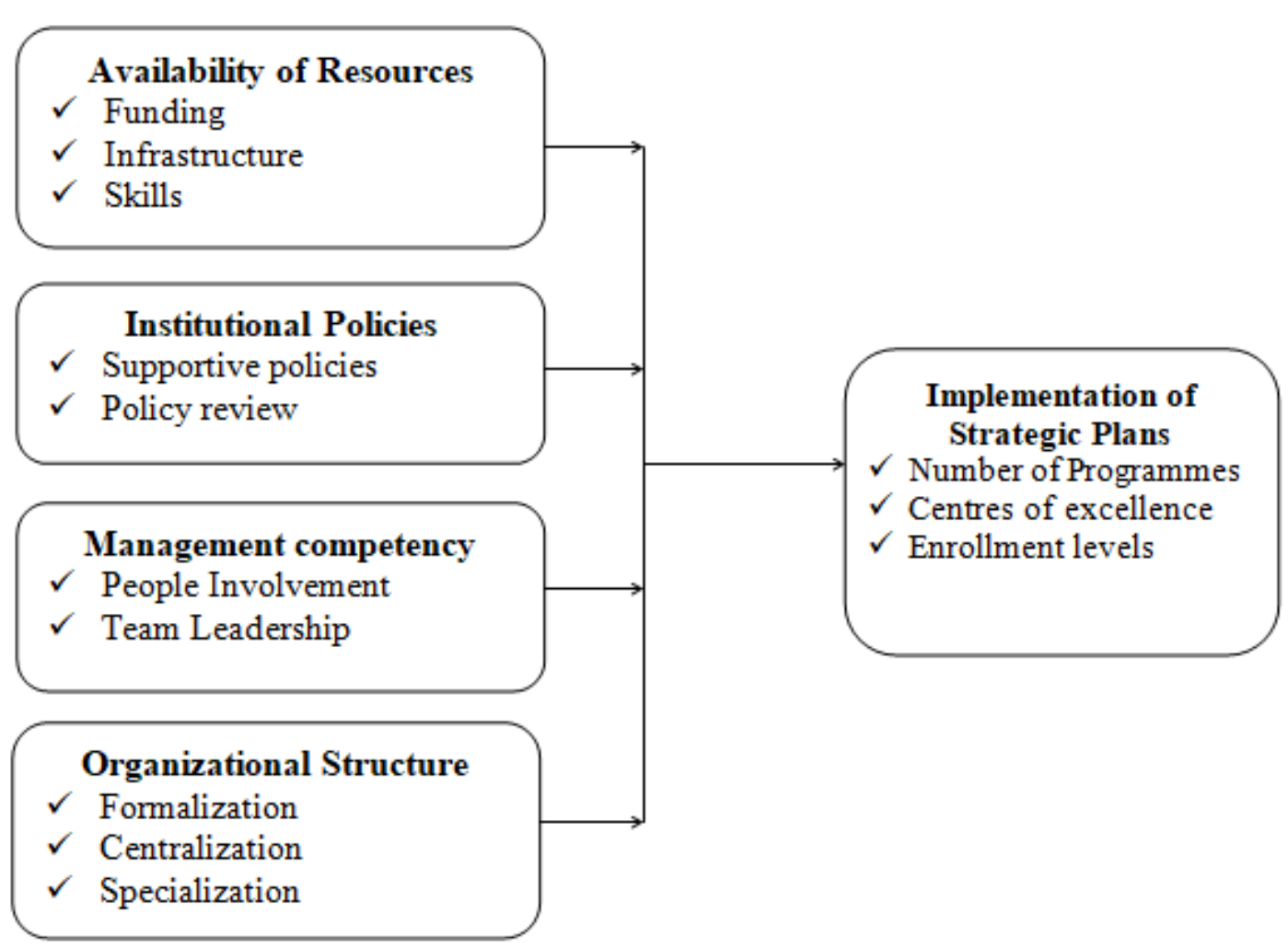

Figure2.1. Conceptual Framework

\section{METHODOLOGY}

A descriptive survey approach was adopted to justify the relationship between the independent and dependent variables. The target population was the TVET colleges in Nairobi. There were 8 TVET colleges in Nairobi as at December 2018 and these will form the unit of analysis (AMFI, 2018). The target population was the three major levels of management (top, middle and bottom level). This gave a total of 32 respondents.

The study used census since the targeted population is considerably small. Therefore, in our case there are 3 TVET institutions in Nairobi. The Heads of Departments and the principal were purposively sampled in each of the institutions. One of the institutions (Kinyanjui TTI) had 7 departments while the other two (Nairobi TTI and Kabete TTI) had nine (9) departments each. This gave a total of 28 respondents ( $25 \mathrm{HoDs}+3$ Principals).

The study relied on primary data which was collected using a questionnaire. Data was analyzed qualitatively and quantitatively. Qualitative data was analyzed using content analysis whereas quantitative data was analyzed using Descriptive statistics analysis which was done by measuring central tendencies which include frequencies, means, standard deviations and regression. Descriptive statistics were done using the Statistical Package for Social Sciences (SPSS). Inferential statistics which includes correlation ( $r$ ) and regression $\left(\mathrm{R}^{2}\right)$ through the use of Multiple Linear Regression model was employed to establish the significance of the independent variables on the dependent variable. The following multiple regression model was applied

$\mathbf{Y}=\boldsymbol{\beta}_{0}+\boldsymbol{\beta}_{1} * \mathbf{X}_{1}+\boldsymbol{\beta}_{2} * \mathbf{X}_{2}+\boldsymbol{\beta}_{3} * \mathbf{X}_{3}+\boldsymbol{\beta}_{4} * \mathbf{X}_{4}+\mathbf{e}$

Where;

$\mathrm{Y}=$ Competitiveness of Micro-Finance Institutions (Dependent Variable)

$\mathrm{B}_{0}=$ Constant

$\beta_{1}, \beta_{2}, \beta_{3}, \beta_{4}=$ coefficients 
$\mathrm{X}_{1}=$ Accessibility of Resources (Independent Variable)

$\mathrm{X}_{2}=$ Management Competency (Independent Variable)

$\mathrm{X}_{3}=$ Institutional Policies (Independent Variable)

$\mathrm{X}_{4}=$ Organizational Structure (Independent Variable)

$\mathrm{e}=$ error term

\section{FINDINGS AND DISCUSSION}

\subsection{Descriptive Statistics}

The first objective of the study was to examine the influence of resource allocation on the implementation of strategic plans in TVET colleges in Nairobi. The findings revealed that on the first aspect that my organization is committed on allocating adequate resources to the operations to promote performance, majority of the respondents agreed as evidenced by a mean of 4.36 and a standard deviation of 0.73 . The findings imply that resources are critical in promoting the strategy implementation and competitiveness. This compares with the findings by Mahasi (2016) who established that as a result of allocation of resources to the organizational operations and ensuring the resources are effectively used ensures proper performance and efficiency thus promoting competitiveness.

The second objective of the study was to determine the influence of institutional policies on the implementation of strategic plans in TVET Colleges. The findings revealed that on the first statement which is that there are properly articulated roles and responsibilities in our organization, majority of the respondents agreed. The findings imply that the roles and responsibilities accorded to the employees play a key role in promoting the effectiveness and commitment of the employees which is critical to strategy implementation. According to Scholes (2012), strategy implementation requires that the roles and responsibilities in an organization are well articulated hence enabling the employees to focus on operations of competitiveness and strategy implementation.

The third objective of the study was to find out the influence of management competency on the implementation of strategic plans in TVET colleges. The findings revealed that majority of the respondents agreed that the management of the institutions was committed towards involving the employees in the decision making process so as to keep them on board as evidenced by a mean of 3.93 and a standard deviation of 0.91 . The findings imply that management competency is critical in enhancing the implementation of strategic plans and how effective the organizations goals are achieved. The findings compare with those by Jayachandran and Bearden (2015) who established that through proper leadership/management styles that are people based, the ability of the employees to implement key strategies by the organization is enhanced.

The fourth objective of the study was to assess the influence of organizational structure on the implementation of strategic plans in TVET colleges. The findings portrayed that flexible organizational design enhances the development of the organization through enhanced communication, most of the respondents agreed with the statement. The findings imply that as a result of properly organized organization structure, strategy implementation was enhanced. The findings are in line with those by Nwonu (2017) who found that organizational structure determined how effective the operations of an organization are and how departments relate to each other thus enabling them to work towards a common goal.

\subsection{Inferential Analysis of the Regression Model}

The model equation was of the form:

$\mathbf{Y}_{\mathrm{s}}=\boldsymbol{\beta}_{0}+\mathbf{B}_{1} \mathbf{X}_{1}+\mathbf{B}_{2} \mathbf{X}_{2}+\mathbf{B}_{3} \mathbf{X}_{3}+\mathbf{B}_{4} \mathbf{X}_{4}+e$

The results indicate that all the variables had P-values less than the standard p-value of 0.05.The regression coefficient results were also sought as shown in table 4.1. The results revealed that the coefficient $\beta$ for the model was 0.791 (constant) and 0.355, 0.783, 0.413, and 0.861 (variables) for availability of resources, institutional policies, management competency and organizational structure, thus making the overall model equation to be; 
Institutional Factors Affecting Implementation of Strategic Plans in TVET Institutions in Nairobi County, Kenya

$Y=0791+0.355 X_{1}+0.783 X_{2}+0.413 X_{3}+0.861 X_{4}$

Table4.1. Regression Coefficients (Overall Model)

\begin{tabular}{|c|c|c|c|c|c|c|}
\hline \multirow{2}{*}{\multicolumn{2}{|c|}{ Model }} & \multicolumn{2}{|c|}{$\begin{array}{l}\text { Unstandardized } \\
\text { Coefficients }\end{array}$} & \multirow{2}{*}{$\begin{array}{l}\text { Standardized } \\
\text { Coefficients } \\
\text { Beta } \\
\end{array}$} & \multirow[t]{2}{*}{$\mathbf{t}$} & \multirow[t]{2}{*}{ Sig. } \\
\hline & & B & Std. Error & & & \\
\hline \multirow[t]{5}{*}{1} & (Constant) & .791 & .183 & & 4.319 & .000 \\
\hline & Availability of Resources & .355 & .056 & .462 & 6.327 & .000 \\
\hline & Institutional Policies & .783 & .105 & .762 & 7.463 & .000 \\
\hline & Management competency & .413 & .026 & .549 & 15.673 & .001 \\
\hline & Organizational Structure & .861 & .040 & .858 & 21.440 & .000 \\
\hline
\end{tabular}

\section{CONCLUSION}

The study concluded that access to resources and allocation of these resources effectively to the organizational operations had a significant influence in enhancing the achievement of the organizational goals and enhancing strategy implementation. Through proper human resources, technological infrastructure and proper financing kept the operations smoothly running hence providing a room for strategy implementation and achievement of competitive advantage.

The study concluded the institutional policies had a positive influence on implementation of strategic plans in TVET Colleges. The study concluded that the management competency employed by the organizational leadership/management play a key role in promoting the strategy implementation. Through employee involvement and encouragement of teamwork, the work is adequately done and problem solving enhanced and this steers productivity hence achieving the goals of the institution.

It was further concluded that organizational structure had a significant influence on the implementation of strategic plans among TVET colleges. Through adoption of properly designed organizational structures, the communication and information sharing among the employees and the departments as well is enhanced thus influencing performance. Strategy implementation in such a scenario is enhanced thus providing better ground for competitiveness and continued performance.

\section{REFERENCES}

[1] Cullati, Stéphane; Kliegel, Matthias; Widmer, Eric (2018). "Development of reserves over the life course and onset of vulnerability in later life". Nature Human Behaviour. 2 (8): 551-558.

[2] Dalton, D. R., \&Kesner, I. F. (1985). Organizational performance as an antecedent of inside/outside chief executive succession: An empirical assessment. Academy of Management Journal, 28: 749-762.

[3] Dario, J. I. (2016). The Impact of Transformational Leadership on Performance Management: A South African Local Government Case Study. Centre for Policy Studies Johannesburg, 20(7): 1 - 26.

[4] Elnaga, A. \& Imran, A. (2013). The Effect of Training on Employee Performance. European Journal of Business and Management, 5 (4), 137-147.

[5] Fiedler, F. E. (1964). A theory of leadership effectiveness. In L. Berkowitz (Ed.), Advances in experimental social psychology. New York: Academic Press.

[6] Gakungu, N. K., Gitau, A. N., Njoroge, B. N. K., \&Kimani, M. W. (2012). Solid waste management in Kenya: a case study of public technical training institutions. ICASTOR Journal of Engineering, 5(3), 127138.

[7] Gorelik, G. (1975) Reemergence of Bogdanov's Tektology in. Soviet Studies of Organization, Academy of Management Journal. 18/2, pp. 345-357.

[8] Gupta, A. (n.d.). Leadership Development - Practical Management. Retrieved October 20, 2016, from http://practical-management.com/Table/Leadership-Development/feed/atom.htm.

[9] Hauser, J. R. and Shugan S.M. (1980), "Intensity Measures of Consumer Preference," Operation Research, Vol. 28, No. 2, 278-320.

[10] Ireri, A. \&Deya, J. (2019). Influence of strategic plan implementation drivers on the performance of automobile companies in Kenya. International Academic Journal of Human Resource and Business Administration, 3(5), 279-295

[11] Katz, D., Kahn, R.L. 1978. The Social Psychology of Organizations, II ed. New York: Wiley.

[12] Kiiru, D. M. (2015). Strategic Human Resource Management Practices and Performance of Parastatals in Kenya. Unpublished PHD Thesis, Kenyatta University. 
[13] Lehtimäki, H. \&Karintaus, K. (2012). Social capital for strategic sensitivity in global business. South Asian Journal of Business and Management Cases, 1(2), 85-98.

[14] Lunceford, Brett (2009). "Reconsidering Technology Adoption and Resistance: Observations of a SemiLuddite". Explorations in Media Ecology. 8 (1): 29-47.

[15] Morin, E. (2008). On Complexity. Cresskill, NJ: Hampton Press.

[16] Nabwonya, D. W. (2016). Determinants of Leadership Styles of Microfinance Institutions in Kenya. International Journal of Finance, 8 (1); 17-25.

[17] Ndegwa, D., M. (2014).Factors Affecting the Implementation of Strategic Plans in Public Secondary Schools in Nyeri County, Kenya. International Review of Management and Business Research Vol. 3 Issue. 2; 993-1002

[18] Njagi, L., \& Kombo, H. (2014). Effect of Strategy Implementation on Performance of Commercial Banks in Kenya. European Journal of Business and Management, 6(13), 62-68.

[19] Palmer, D., \& Barber, B. M. 2001. Challengers, elites, and owning families: A social class theory of corporate acquisitions in the 1960s. Administrative Science Quarterly, 46: 87-120

[20] Pearce J. \& Robinson, B. (2007). Strategic Management: Strategy Formulation and Implementation, Richard D. IRWIN, INC. Homewood, Illinois 60430.

[21] Pfeffer, J., \&Salancik, G. R. (1978). The external control of organizations: A resource dependence perspective. New York: Harper \& Row.

[22] Poku, D. (2012). The Effect of Strategic Planning on The Performance and Operations of the Agricultural Development Bank.

[23] Tapera J. (2016) the importance of strategic management to business organizations. International Journal of Social science Management. 4(16). Retrieved from https://www.researchgate.net/publication/301801352 20.

[24] Walsh, J., Weber, K. \& Margolis, J., (2013). Social Issues \& Management: Our Lost Cause Found`, Journal of Management, 29, 6, pp. 859-881

[25] Wanyonyi, S. C., \&Muturi, W. (2015). Factors affecting performance of procurement function among public technical training institutions in Kisumu County, Kenya. International Journal of Economics, Commerce and Management, 3(5), 325-337.

[26] World Bank. (2011). Strategic planning: a ten-step guide, 2011. Retrieved from https://siteresources. worldbank.org/INTAFRREGTOPT EIA/ Resources/mosaica10_steps.pdf

\section{AUTHOR'S BIOGRAPHY}

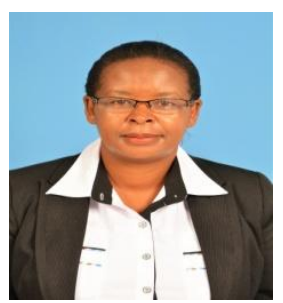

Monica N. Gachunga, holds an MBA in strategic Management. Currently, she is a finalist $\mathrm{PhD}$ candidate in Business Administration (Strategic Management option) at Jomo Kenyatta University of Agriculture and Technology, Nairobi Kenya. She has wide experience in accreditation and quality assurance in Higher Education. Currently, she is working at the Commission for University Education, Nairobi Kenya in a senior Management level.

Citation: Monica Njeri Gachunga. "Institutional Factors Affecting Implementation of Strategic Plans in TVET Institutions in Nairobi County, Kenya" International Journal of Managerial Studies and Research (IJMSR), vol 8, no. 12, 2020, pp. 39-45. doi: https://doi.org/10.20431/2349-0349.0812004.

Copyright: (c) 2020 Authors. This is an open-access article distributed under the terms of the Creative Commons Attribution License, which permits unrestricted use, distribution, and reproduction in any medium, provided the original author and source are credited. 